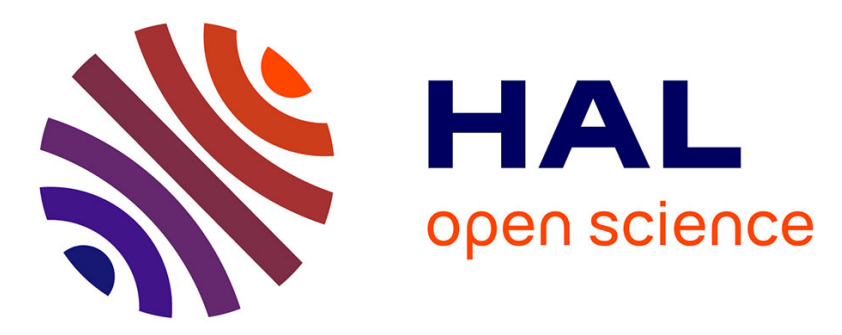

\title{
Using a small COTS UAV to quantify moraine dynamics induced by climate shift in Arctic environments
}

Eric Bernard, Jean-Michel Friedt, Florian Tolle, Christelle Marlin, Madeleine

Griselin

\section{- To cite this version:}

Eric Bernard, Jean-Michel Friedt, Florian Tolle, Christelle Marlin, Madeleine Griselin. Using a small COTS UAV to quantify moraine dynamics induced by climate shift in Arctic environments. International Journal of Remote Sensing, 2016, 38 (8 - 10), pp.2480 - 2494. hal-02963430

\section{HAL Id: hal-02963430 \\ https://hal.science/hal-02963430}

Submitted on 10 Oct 2020

HAL is a multi-disciplinary open access archive for the deposit and dissemination of scientific research documents, whether they are published or not. The documents may come from teaching and research institutions in France or abroad, or from public or private research centers.
L'archive ouverte pluridisciplinaire HAL, est destinée au dépôt et à la diffusion de documents scientifiques de niveau recherche, publiés ou non, émanant des établissements d'enseignement et de recherche français ou étrangers, des laboratoires publics ou privés. 
To appear in the International Journal of Remote Sensing

Vol. 00, No. 00, Month 20XX, 1-14

\title{
Using a small COTS UAV to quantify moraine dynamics induced by climate shift in Arctic environments.
}

\author{
É. Bernard ${ }^{\mathrm{a} *}$, J.M. Friedt ${ }^{\mathrm{b}}$, F. Tolle ${ }^{\mathrm{a}}$, Ch. Marlin ${ }^{\mathrm{c}}$ and M. Griselin ${ }^{\mathrm{a}}$ \\ ${ }^{a}$ CNRS, ThéMA-UMR 6049, Univ. of Bourgogne Franche Comté, Besançon, France; \\ ${ }^{b}$ FEMTO-ST-UMR 6174, CNRS, Univ. of Bourgogne Franche Comté, Besançon, France \\ ${ }^{c}$ GEOPS-UMR 8148, CNRS, Univ. of Paris-Sud, Orsay, France
}

(September 8, 2016)

\begin{abstract}
Arctic regions are known to be places where climate shift yields the most visible consequences. In this context, glaciers and their environment are highly subject to global warming effects. New dynamics are observed and the behavior of arctic systems (such as glaciers, moraines, beaches etc) changes at rates visible over yearly observations.

According to recent works on climate change impacts on the cryosphere, short/violent events are recently observed and are one characteristic of these changes. As a consequence, an accelerating rate of glacial and pro-glacial activity is observed, especially at the end of each hydrological season (early fall). As an example, many phases of streamflow increase/decrease are observed, transforming glacier outflows, moraine morphology and re-organizing intra-moraine processes. Within only a few days, the morphology of some parts of the moraine can be completely changed.

In order to observe and quantify these processes, reactive methods of survey are needed. That is why the use of commercial, off the shelf (COTS) - DJI Phantom3 Professional - Unmanned Aerial Vehicle (UAV) for aerial photography acquisition, combined with Structure from Motion (SfM) analysis and Digital Elevation Model computation, were chosen. The robust architecture of this platform makes it well suited as a reliable picture acquisition system for high resolution (sub-decimeter) imaging. These increasingly popular methods, at a convergence of technologies including inertial guidance systems, long lasting batteries and available computational power (both embedded and for image processing), allow to fly and to acquire data whatever the conditions of cloud cover. Furthermore, data acquisition is much more flexible than traditional satellite imagery: several flights can be performed in order to obtain the best conditions/acquisitions at a high spatio-temporal resolution. Moreover, the low-flying UAV yielding high picture resolution allows to generate high resolution digital elevation models and therefore to measure accurately dynamics on the field with decimeter resolution in all 3 directions.

Our objective is to show an experimental campaign of small UAV data acquisition in an arctic basin (Austre Lovén glacier, Svalbard, $78^{\circ} \mathrm{N}$ ) separated by a few days. Knowing the changing conditions at this period, similar UAV flights have been reiterated in order to catch moraine dynamics. This allowed us to select two sets of images whose processing highlights and quantifies morphological changes into the moraine while a rain event occurred between two cold periods.
\end{abstract}

Keywords: UAV; Structure from Motion; Arctic; Moraine dynamics; Climate shift

*Corresponding author. Email: eric.bernard@univ-fcomte.fr 


\section{Introduction}

\subsection{Context of the work}

Today, glacier basins are a confirmed and well-observed proxy for estimating the impact of global climate shift as shown by Oerlemans (2005) and Moholdt et al. (2010). Glacier dynamics and especially annual mass balance is one of the main indicators which allows to quantify the climate influence on the cryosphere (Hagen and Liestøl (1990); Lefauconnier et al. (1993); Hock (2005)). Through mass balance study, it is possible to better understand glacier behavior facing phenomena such as global warming. But according to Park et al. (2013); Radić et al. (2013), global climate change does not only impact glacier melt as often mentioned, but also the global cryosphere dynamics with strong uncertainties. Concerning geomorphological consequences, they are sometimes more difficult to evaluate since they are less visible or they appear with a temporal inertia. However, since the Little Ice Age (LIA), the general trend of glacier retreat reshapes para-glacial environment (Rachlewicz (2010); Wiesmann et al. (2012)), revealing new spaces, particularly downstream, in the moraine. This area, under the influence of fast glacial retreat, tends to become larger than the glacier itself as described by Friedt et al. (2011). Thus, these ice-marginal landforms are a fundamental source of information about the extent and dynamics of former glaciers (Humlum (2000); Paul (2010); Barr and Lovell (2014); Birks et al. (2014)). If they are widely used to reconstruct the dimensions of former ice masses and paleoclimate, moraines also give important clues on climate change impact through their present dynamics (Evans (2009)). This new ice-free area is not yet completely stabilized and thus exposed to significant movements and geomorphologic changes. Even tiny climatic parameters can influence significantly moraine dynamics and morphology (Bernard et al. (2013)).

In such a fast-changing environment, fieldwork with classical measurement methods needs to be completed with larger scale investigations through remote sensing observations (Colomina and Molina (2014)). Space-borne remote sensors have high temporal and global coverage and remote sensing-based analysis reduces the need for frequent and regular fieldwork. However, space-borne remote sensing platforms have their own limitations (Westoby et al. (2012)). First, data are acquired on specific dates or at a specific time. Data acquisition depends upon the satellite's revisit or temporal resolution. Moreover, a second limitation consists in the meteorological conditions which influence the data quality. In Arctic, cloud cover is a persistent problem for usable acquisitions, and obtaining cloud-free data is yet a great challenge (Bernard et al. (2013)). Nevertheless, as assessed by many works (Niethammer et al. (2012); Westoby et al. (2012); Lucieer et al. (2014)) these limitations can easily be overcome by the use of unmanned aerial vehicles (UAVs).

\subsection{Objective of the study}

The moraine is an area where processes are strongly linked to meteorological parameters, and where their consequences are highly visible. According to Bennett (2001), newly deglaciated areas left by glacial retreat have a fast morphological response time, especially to liquid precipitations and temperature shifts. These exposed forelands are supposed to be subject to intensive geomorphological processes due to the paraglacial adjustment of the topography (Rachlewicz (2010); Midgley et al. (2013)). Indeed, during several field campaigns, we observed the fast response of the moraine, emphasized following violent climate events such as heavy rains and sudden increase of air temperature (AT). 
Thus, in this work, the main focus deals with the short-term (weekly) dynamics of moraines. In such an approach, a high spatio-temporal resolution observation is needed. This helped us in framing the following objectives of the present paper:

- the first point is to assess the use of UAVs and associated data processing methods to observe and measure para-glacial processes and dynamics in a climate change context,

- the second point is to highlight, through these methods and observations close in time, the impact of so called warm/rain events on an Arctic environment.

\section{Geographical settings}

\subsection{Fieldwork and geomorphological parameters: the moraine as a climate shift witness}

The study was carried out in a glacial basin located on the West coast of Spitsbergen (high-Arctic), on the north side of the Brøgger peninsula $\left(79^{\circ} \mathrm{N}, 12^{\circ} \mathrm{E}\right)$ (Fig. 1). In a $10.58 \mathrm{~km}^{2}$ basin, Austre Lovén is a small land-terminating valley and polythermal glacier. It covers an area of $4.5 \mathrm{~km}^{2}$, with a maximum altitude of no more than 550 m.a.s.l.

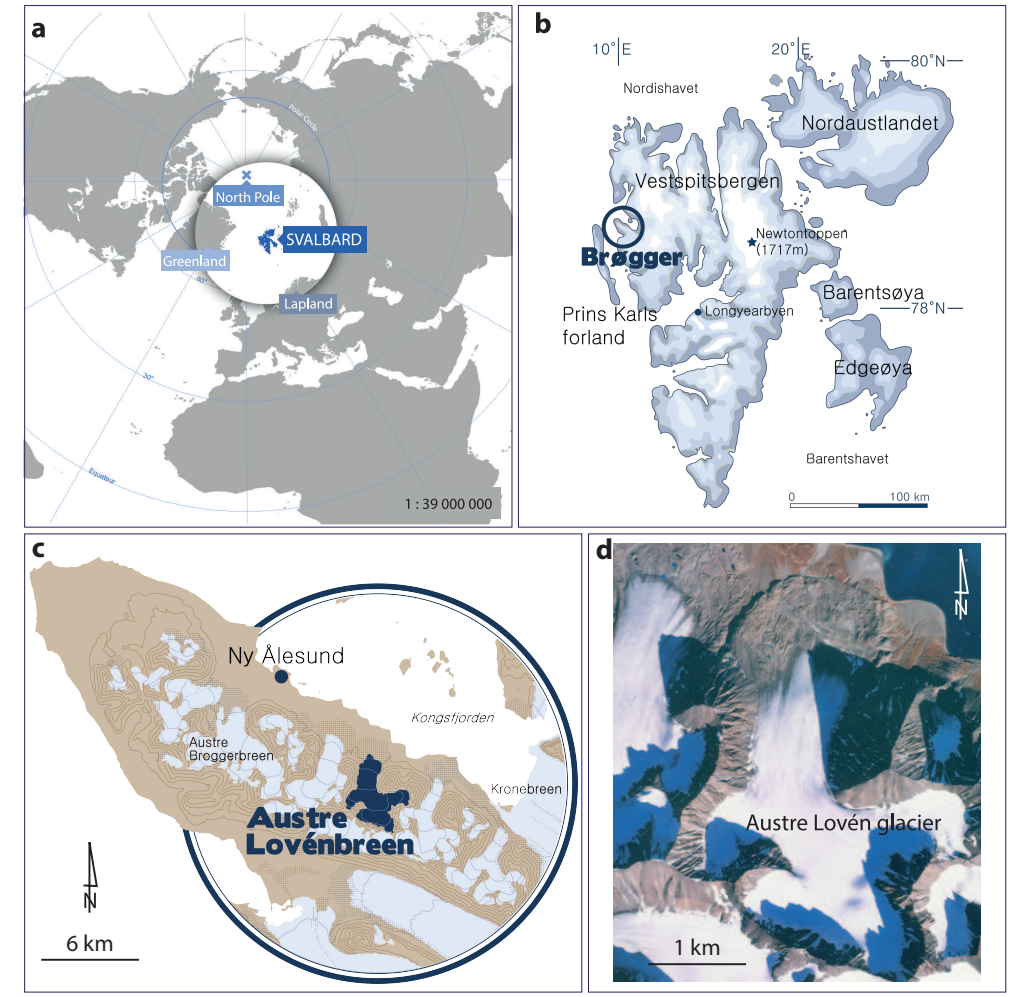

Figure 1. Field work is located in the high-Arctic, on the West coast of Spitsbergen. Austre Lovén is a small land terminating glacier, chosen by scientists since the early 60 s for its geomorphological characteristics.

This small basin is representative of the geomorphology of Spitsbergen West coast (Kohler et al. (2007)). While the study area is located in the high-Arctic with a strong maritime influence and relatively low altitudes, the general morphology is clearly Alpine, as shown in Fig. 1 (d). In the current context, glacier retreat 
gives the opportunity to observe the dynamics of morainic material. It plays a significant role in the hydro-glaciological processes (Griselin and Marlin (1998); Hodgkins (1997); Ferguson (1999); Ewertowski and Tomczyk (2015)), specifically on the runoff and meltwater organization (Wright (2005)).

Front and marginal moraines are pro-glacial ridge-like formations. They were formed both through supra-glacial and sub-glacial processes: gradually, debris is spilled at glacier margins (Bennett et al. (1999); Bennett (2001)).

Austre Lovén glacier lies on relatively shallow bed slopes: it is therefore likely to deposit a large number of comparatively small moraines, as ice margins fluctuate in response to minor variations in climate (Lønne (2007)). The parts of the moraine furthest away from the glacier snout are the oldest and hence most stable, while the area of interest here is the newly deglaciated area close to the glacier front.

Thus, in the current context of climate change, the moraine is a complex sedimentary system with increasing dynamics. Like many other similar glaciers in the surrounding area, the front of Austre Lovén has receded by around $1 \mathrm{~km}$ since the Neoglacial maximum extent at the end of the nineteenth century. As illustrated in Fig. 2, during the last decades, the glacier forefield extended, with new processes, especially concerning hydrological dynamics. As shown on Fig. 2, we observe an average length change of $-16 \mathrm{~m} \cdot \mathrm{a}^{-1}\left(-19 \mathrm{~m} \cdot \mathrm{a}^{-1}\right.$ along the central flow line).

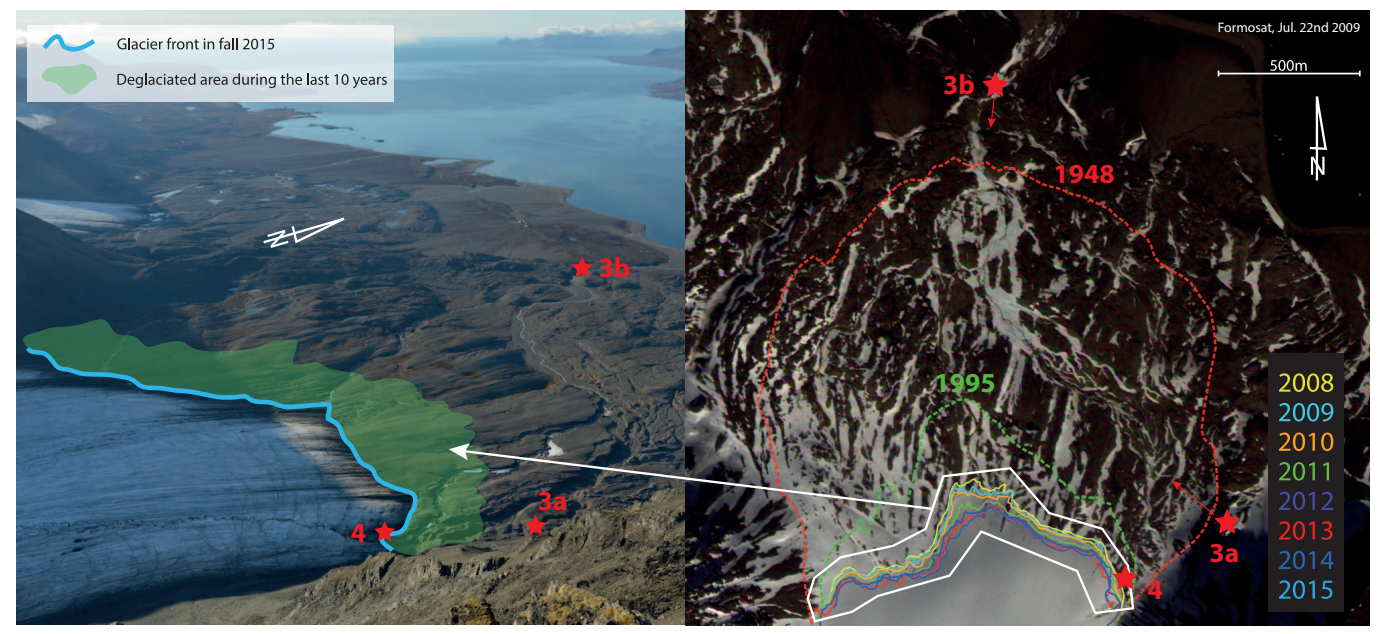

Figure 2. Moraine dynamics and glacier retreat since 1948. This retreat is continuous since the LIA and the glacier front has become a key area due to its significant movements and changes from one hydrological season to another. Stars indicate the location of pictures shown in Figs. 3 and 4, with associated arrows indicating the viewing direction. The colored legend refers to the front positions closest to the current glacier limit.

\subsection{Impact of "warm events" on moraine dynamics}

Each year, events with abnormally high positive air temperature (so called warm events) are observed, whatever the season of the year (Nowak and Hodson (2013)). Fig. 3 shows how sudden and violent could the associated dynamics be. In spring, melt water from icings are the main component of the pro-glacial hydrology. Indeed, icings are large reservoirs of water that react immediately to positive AT conditions. A sudden increase of temperatures, with strong liquid precipitations may trigger a massive influx of water, saturating the entire snowpack. In fall, while winter conditions are set up, major floods can appears, following a sudden rain event with rising temperatures. This second point is the context of this paper. 

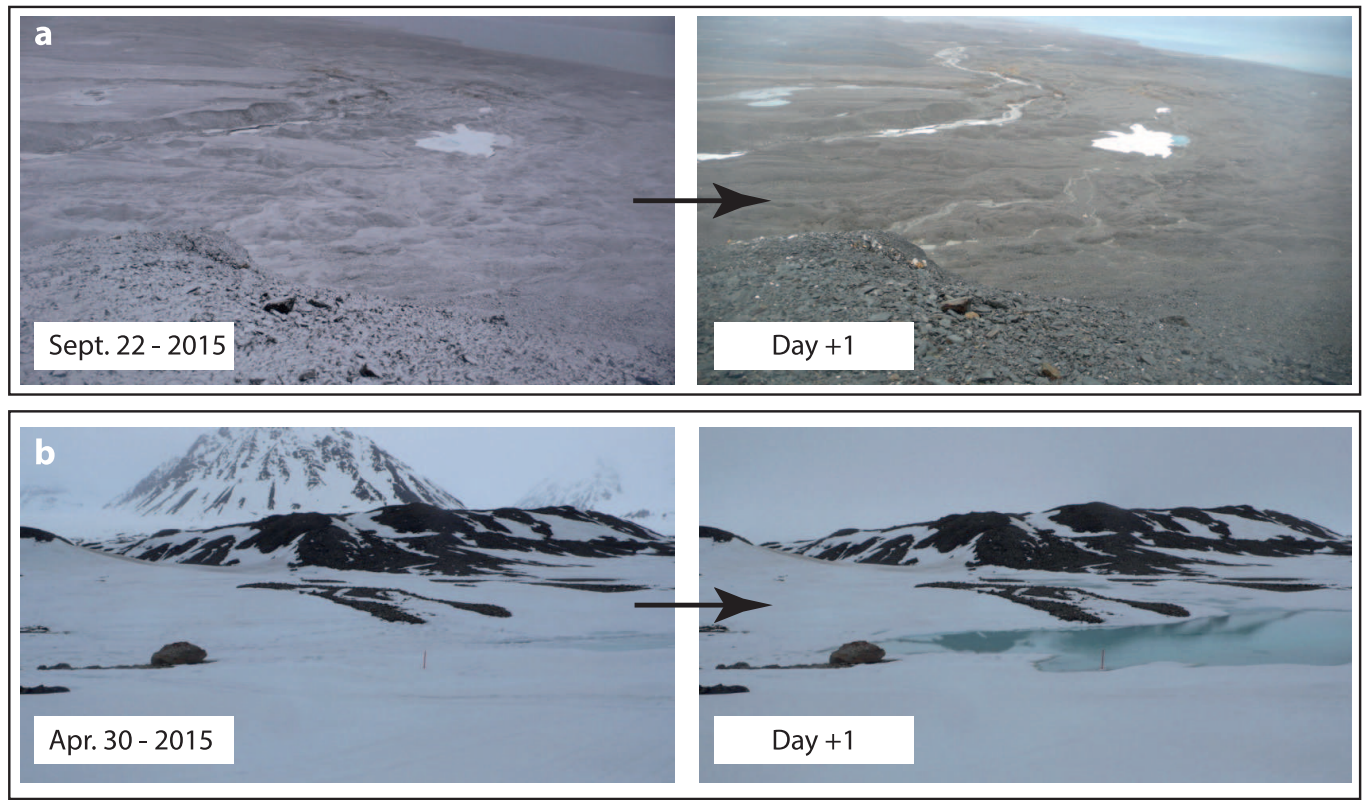

Figure 3. (a) In fall, a sudden flood can appear with an important flux of sediment and moraine geomorphology change, while (b) in spring, icings in the moraine are directly affected by a massive influx of water into the snowpack. The view shown in (a) is taken by an automated time-lapse camera, covering a large area of the East part downstream the moraine, as visible in Fig. 2. (b) is located nearby the limestone outcrop at the main outlet of the basin, also shown with the star $3 \mathrm{~b}$ on top of Fig. 2.

To recognize how high the activity of such sudden events is, we focused here on one of the main intra-morainic canyon, and especially on its upstream part, on a $200 \mathrm{~m}$ wide strip near the glacier front (Fig. 4). Indeed, this part was newly deglaciated during the last 10 years, and is even more subject to geomorphological changes. This massive canyon drains the main outlet of Austre Lovén glacier. It is thus a key area of interest to study, since it is known (Irvine-Fynn et al. (2011); Rutter et al. (2011)) that river meltwater outflows react to AT variations immediately or within short delays.

\section{Methods and data}

\subsection{Small COTS UAV and SfM photogrammetry: the best suited combination for Arctic environment?}

According to a large body of literature (e.g. Westoby et al. (2012); Colomina and Molina (2014); Kenner et al. (2014); Rippin, Pomfret, and King (2015)), "Structure-from-Motion" photogrammetry is a low-cost and effective tool for geoscience applications. In our study, this method seems to be perfectly suited, while applied on glaciological and para-glaciological dynamics, for generating large scale ortho-photos and digital elevation models (DEM). Considering the characteristics of both Arctic climate and mountain terrain, these methods (from acquisition to processing), were thus applied on Austre Lovén glacier catchment.

Considering that specifically harsh environment, a small, lightweight and efficient UAV was needed. Hence, we used a low-cost, commercial off the shelf UAV, DJI Phantom 3 Professional (Fig. 5). After trying different types of UAVs, this equipment provided the best tradeoff between image quality and ease of use on the field and lightweight equipment to be carried on the field in mountain type/harsh 


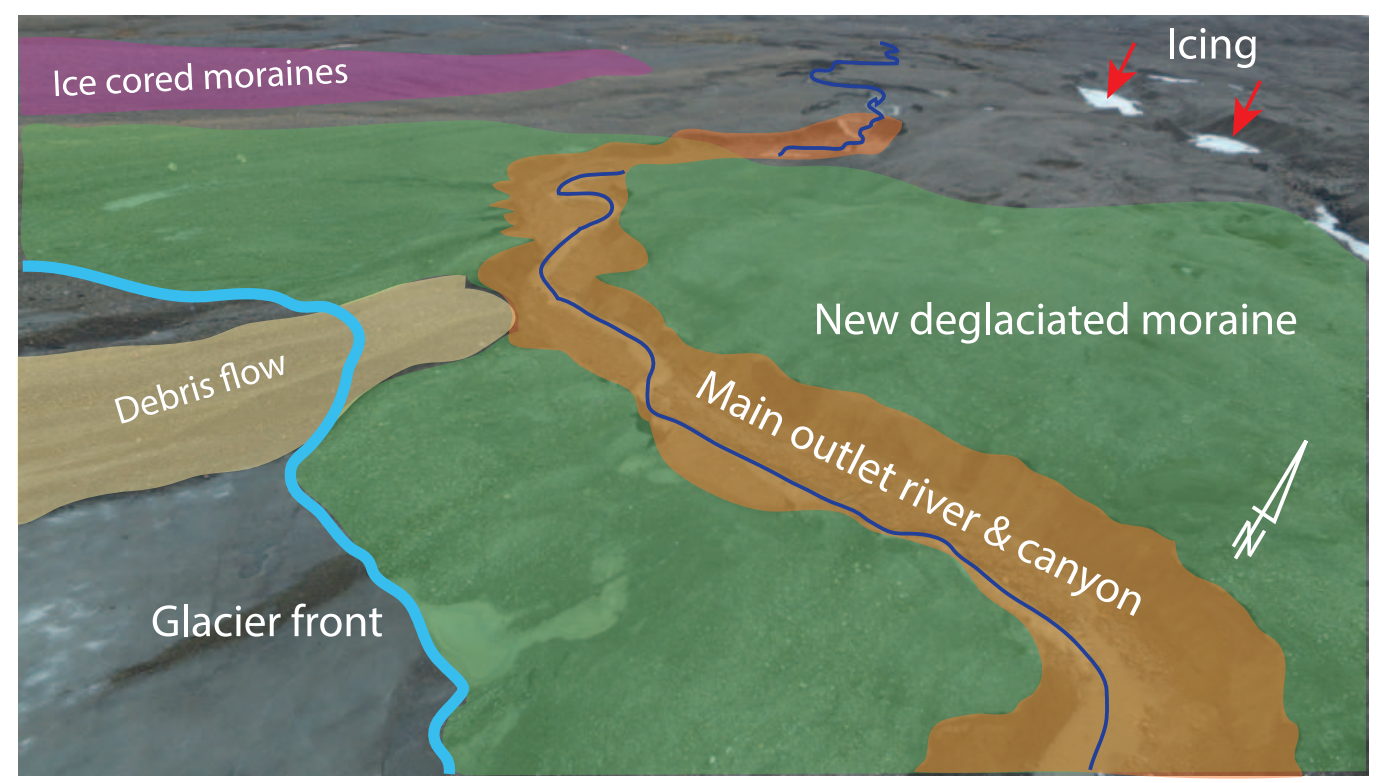

Figure 4. The newly deglaciated moraine consists in a $200 \mathrm{~m}$ wide strip at the front of the glacier (light green). It represents the glacial retreat over the last 10 years, and is the area where geomorphological processes are the most active. The location from which the picture was taken is indicated in Fig. 2 with the star named 4, with a viewing direction towards the North-West, giving a hint of the scale of the features visible here.

climate environment. A single operator can manage both flight control and image acquisition. As will be demonstrated here, the camera lens gives a sub-decimeter resolution sufficient for geoscience applications. Hence, there is no need to use a higher resolution camera which could be time consuming and bring difficulties during the processing step due to images size, while lens modeling was accurate enough to allow for the photogrammetric processing chain to converge.

To obtain the best accuracy, Ground Control Points (GCPs) were positioned prior to each flight over strategic parts of the moraine. We used 30-cm diameter hard plastic gardening saucers, pink colored, easy to point on photos (Fig. 5) during the data processing step. GCP positioning onto the moraine is a time consuming task due to the slow pace of walking in the rough terrain, with some key points hard to reach, but most significantly due to the time needed for GCP position recording with a dual-frequency GPS Trimble package (Geo XH device with Zephir antenna). Therefore, in order to complete this GCP network, remarkable points (such as erratic boulder) were also used to calibrate photogrammetry processing.

\subsection{UAV images acquisition}

During the fall 2015 field campaign (September-October), we carried out several flights over the Austre Lovén moraine in order to get an accurate DEM and to provide orthophotos of this area. In anticipation of possible bad weather conditions, we started to fly quite early, once the meteorological and aerological conditions were fine. This allowed us to perform 2 main sessions of flights, separated by approximately one week. Flight plans are visible on Fig. 6. We chose to fly manually to adapt to aerial observations thanks to real time feedback, and maximize horizontal speed $(10 \mathrm{~m} / \mathrm{s})$ since automated path planning tools yielded excessively slow pace preventing the analysis of wide swaths of the moraine.

During the first acquisition session - September 24th and 26th 2015 - the moraine 


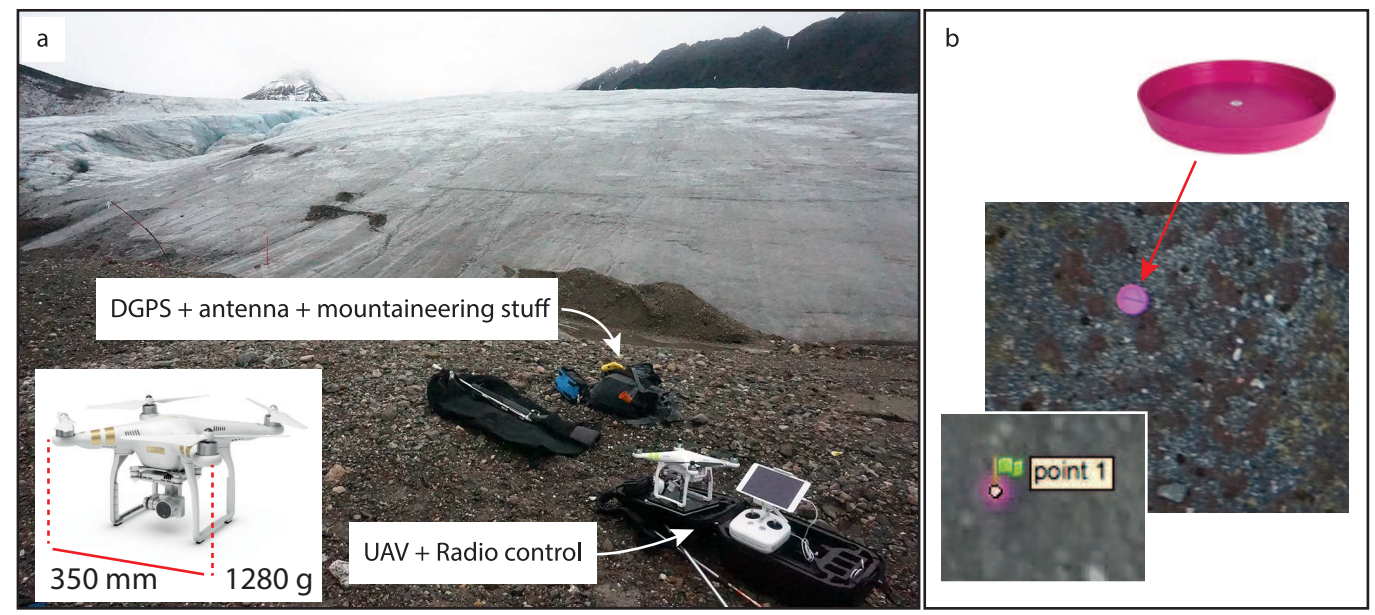

Figure 5. A well suited package for SfM survey in Arctic/mountain terrain and cold regions. All the equipment is easily packable in a backpack and makes travel into the moraine and work easier (a). Pink gardening saucers are perfect GCPs since the environment is monotonous (b).

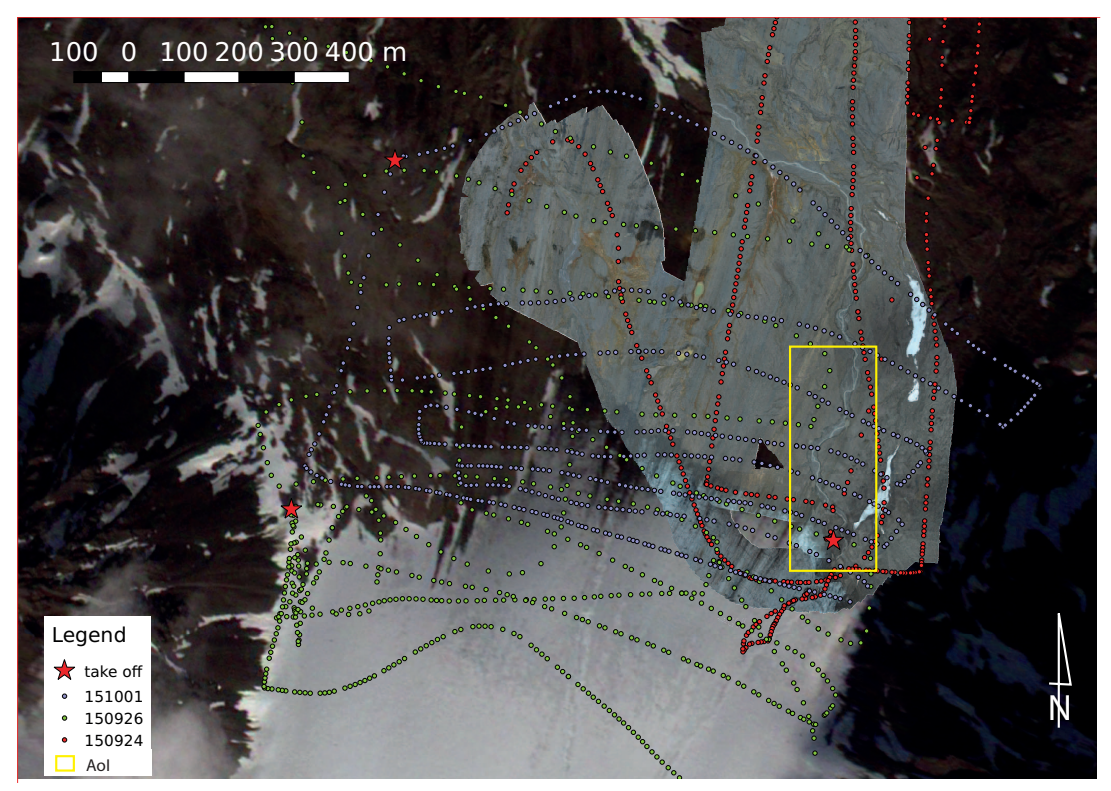

Figure 6. Flight plans of three autumn 2015 field campaigns, colored with respect to the flight dates given in the legend, whose results are described in the text. The yellow rectangle locates the area of interest (AoI) over the upper part of the glacier outlet river. Star markers represent the takeoff locations. The background image has been acquired by Formosat (July 22nd 2009), with the overlap of an orthophoto acquired from our UAV on the eastern side of the moraine.

was free of snow, AT started to drop under $0^{\circ} \mathrm{C}$ while the hydrological network was low-water. Aerological conditions were quite perfect while the problem of cold was overcome by using several batteries on the field. Most of the time, the weather was overcast, without precipitation. Flying height was around $100 \mathrm{~m}$ with a coverage of $120 \mathrm{~m}$ in the flight direction and an overlap of over $80 \%$ (1 picture/second) from an image to another.

During the second session - October 1st 2015 - the same flight parameters were kept. Winter conditions were settled while the hydrological network was largely frozen and $\mathrm{AT}$ dropped under $-3^{\circ} \mathrm{C}$. One issue was the reduced life expectancy of batteries due to the low temperatures. Moreover, a thin but persistent layer of 
snow covered the moraine, making orientation and interpretation more difficult. Snowy weather did not help in performing measurements. Nevertheless, complete coverage was achieved.

\subsection{Data processing: the open source choice}

Data processing is a crucial step. Because digital image processing is prone to the introduction of various artifacts during the complex signal processing steps modeling the lens characteristics, positioning the cameras, coarse and fine point cloud generation, introduction of GCPs and dense point cloud generation - the black box approach provided by most commercial software is not satisfactory: a detailed description of the operating principles of the software, as found for example by reading source code, is a mandatory requirement to assess the confidence in the signal processing results. Hence our selection of the MicMac software ${ }^{1}$ developed by a laboratory of the French National Geographical Institute (IGN) which meets these requirements, with clear separation of the processing steps and a verbose output providing detailed reports on the convergence of each processing step.

As most SfM processing software packages, various means are available for converting the DEM, needed to orthorectify the images, from the arbitrary framework of the images to an absolute geographical coordinate system. The GPS position of the camera as each image was acquired is easiest to obtain, but the single frequency GPS information provided by the COTS UAV only allows for positioning the DEM with an accuracy of $\pm 10 \mathrm{~m}$ in the latitude-longitude plane. Thus, using GCPs is mandatory to reach sub-meter positioning. However, due to the challenge of deploying GCPs on the field over the wide area under investigation, and because we are solely here interested in relative topography evolution, we will not use GCP located during the flight on the ground but use the roughly positioned initial dataset as a reference for the later DEM positioning. The tool Campari from the MicMac suite is designed to constraint the DEM resulting from image processing (affected by lens distortion model errors) on the GCP. Using this additional processing step, based on GCP selected on the initial dataset on regions known not to have moved between the two acquisitions, sub-meter accuracy has been achieved.

\section{Results and discussion}

\subsection{Data assessment}

Considering the camera aperture of $94^{\circ}$ and a flight altitude of $100 \mathrm{~m}$, the pixel size is $4 \mathrm{~cm}$ on the 4000 pixel wide picture. Such a resolution is a significant improvement over satellite imagery limited to a few decimeters at best, and the meter resolution of the Formosat imagery we use as background reference. Most important, this resolution improvement brings some new insight on the geomorphology evolution of the moraine. However, for comparing multiple images acquired with different GPS satellite constellation distributions, image registration is mandatory for quantitative comparison. Throughout this study, GCPs are selected in areas known not to evolve (large erratic boulders, bedrock) and the initial image is used as reference over which all subsequent images are registered. We chose to restrict corrections to translations and prevent scaling and rotation, which would be needed

\footnotetext{
${ }^{1}$ available at logiciels.ign.fr/?-Micmac, 3-
} 
on larger areas, by focusing on small enough regions in which the approximation is valid within a decimeter.

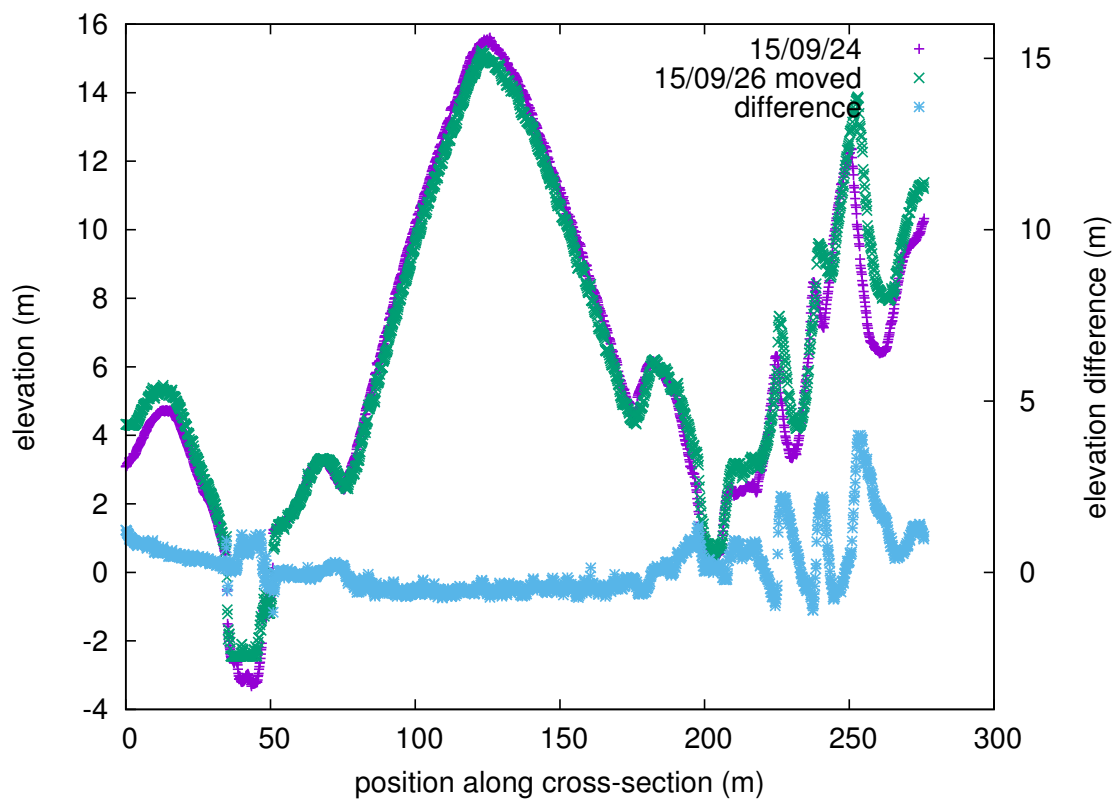

Figure 7. Comparison between 2 static areas in the old moraine which are assumed not to have changed between data acquisition: profiles are extracted from DEMs generated using images acquired September 24th and September 26th 2015, the latter having been moved to match GCPs visible on the orthophotos.

In addition to orthophotos, another SfM product is the DEM. Here again rather than considering absolute elevations, we are interested in the relative difference of DEMs (DoD). Again the initial DEM is considered as the reference, and once the orthophoto has been translated for registration with the initial dataset and the same transform applied to the associated DEM, an additional translation in altitude brings both datasets to comparable altitudes. As an example of DEM comparison, Fig. 7 exhibits the absolute DEM elevation over a length of $280 \mathrm{~m}$ for datasets acquired September 24th and 26th 2015, with the initial $200 \mathrm{~m}$ properly registered and the last $80 \mathrm{~m}$ emphasizing the limitations of the approach with significant discrepancy once the cross profile reaches rugged areas of the moraine. The canyon crossing is visible at abscissa 45 to $50 \mathrm{~m}$. The DEM difference standard deviation between 80 and $180 \mathrm{~m}$ abscissa is $0.11 \mathrm{~m}$.

\subsection{Orthophoto comparison}

Two orthophotos covering a wide area at the sub-glacier river outlet have been assembled, corresponding to the flight sessions of Sept. 24 and Oct. 1st (area of interest shown in Fig. 6) with zooms on one particular region of interest exhibited in Fig. 8. The left-orthophoto is used as reference with GCPs visible as red triangles, while the right orthophoto was translated for these DEMs to match despite the offset of GPS positioning between the two dates. No scaling was needed in the process. One morphological consequence of the flood event is a dynamic of river braiding, which is clearly visible in the center of images displayed in Fig. 8.

According to the glacier melting processes, the river headwater records first the impact of sudden and massive supra- and sub- glacial meltwater outflows. Geomorphologically, we first observe a massive influx of water coming from the glacier 


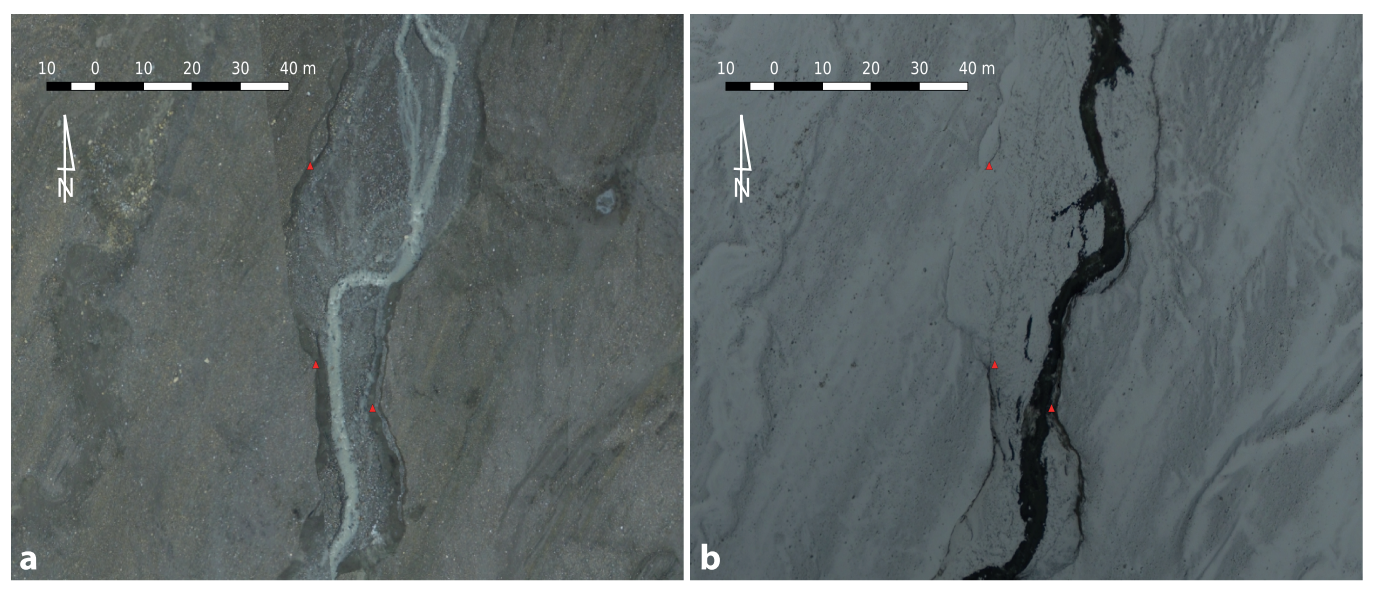

Figure 8. Orthophoto of Sept. 24th 2015 (a). Orthophoto of Oct. 1st 2015 (b). The river bedstream changed significantly up to a maximum of $11 \mathrm{~m}$. Three GCPs are visible as red triangles in both pictures.

itself and both meltwater from the active layer (e.g. groudwater discharge from the supra-permafrost aquifer) and superficial thaw.

To compare the global morphology of the moraine between these 2 dates, generated orthophotos were superimposed in a GIS to map the bedstreams of the river (e.g. before and after the rain event). Comparing the 2 channels, we observe that a single short event changed the morphology of the river channel through processes that:

- dug significantly into the moraine brittle materials. Initial sinuous watercourse became straighter;

- disrupted the river system by changing the flows and thus reshaped a new river bed/river system.

\subsection{Digital Elevation Model for topography change monitoring}

Acquired data allowed to generate 2 DEMs, accurate enough to observe and quantify changes due to strong rainfall and warming. Fig. 9 exhibits a DEM in the context of an underlying Formosat image acquired July 22nd 2009: the generated topography appears consistent with underlying features as observed on satellite image, but most significantly the fine details of the hydrological network is emphasized on the DEM with respect to the aerial image.

Concerning the impact of rain events, we observed that a large amount of both morainic deglaciated rocks and particles eroded and carried by the glacier and then washed into the deglaciated area are movable and then quickly displaced during flood events. This soggy and low cohesion material makes this part of the moraine fragile. It is then an ephemeral space configuration, especially when subjected to these violent climatic events. Massive influx of water in meanders makes the unstabilized banks collapse. An example of such phenomenon is highlighted in Fig. 10. These results also highlight that rain events (and supposedly warm event as well) and their impacts consist in very short period processes. Hence, to record and analyze impacts, an accurate spatio-temporal observation is needed. These results have been obtained thanks to the use of UAV field campaign.

While a rotating wing multicopter appears as suitable to monitor small glaciers and small glacier basins, extending the observation area requires the use of fixed wing UAV for extended flight duration and higher horizontal speed: in these exper- 


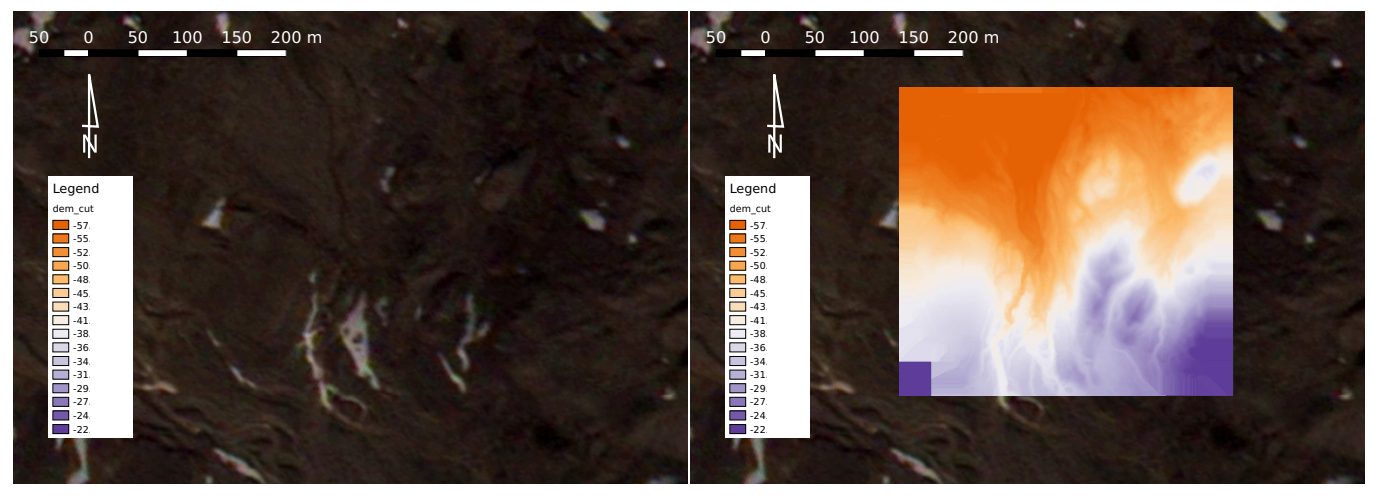

Figure 9. Left: Formosat image acquired July 22nd 2009 of the area of interest. Right: overlap of a DEM acquired Sept. 242015 of the same region, illustrating the consistency and fine hydrological network visible on the topography. The average tilt on the DEM has not been compensated for: water flows from bottom to top.

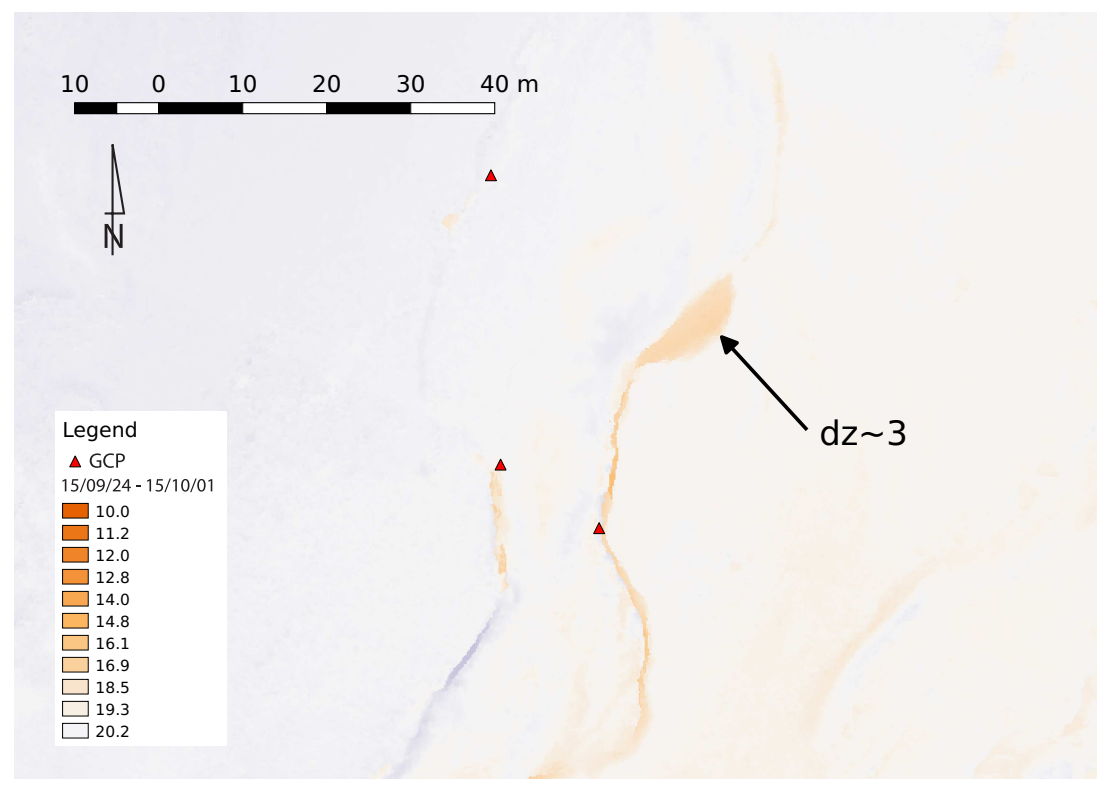

Figure 10. Difference of DEM (DoD) for assessing moraine movements due to a significant flood event, with one wall of the canyon collapsing between the two dates. The images for generating the DEMs were acquired September 24th 2015 and October 1st 2015. The landslide generated canyon collapse depth is about $3 \mathrm{~m}$.

iments, areas ranging from 0.5 to $1 \mathrm{~km}^{2}$ were mapped during each 20 min flight.

\section{Conclusion}

The work carried out assesses both the impact of rain events on moraine geomorphology and Structure from Motion photogrammetric processing applied to aerial pictures acquired from an Unmanned Aerial Vehicle in an Arctic glacier environment. This second point showed that this equipment is light enough to be transported and used by a single operator on harsh fieldwork such as mountain environment and Arctic region.

The flexibility of the whole workflow provides the opportunity to repeat field experiments within short intervals and hence observe fast morphology changes associated with climatic events. Hence, we conclude that 
- photogrammetry approach delivers high quality and high resolution topographic pointclouds, well suited for physical geography investigations,

- this approach is a reactive method suitable to use in a fast changing environment.

This work also highlights the significant impact of short rain precipitations, with associated flood events, on para-glacial geomorphology. Consequences are not only on landscape but also on general processes. Reciprocally, newly deglaciated areas (i.e. less than 10 years old) are quite sensitive to floods created by sudden rain and warm events. This part of the moraine also provides a large amount of sediment in the outflow dynamics. According to the increase of warm event phenomena, this key area in the glacial system undergoes major changes which will tend to increase in the future.

\section{Acknowledgements}

We acknowledge Région Franche Comté for funding UAV acquisition and field trips, and J.-P. Culas (CM-Drones, Besançon, France) for technical support in the maintenance of the UAV. ANR grants PRISM and IPEV grant GRAAL also contributed to the success of these field experiments. M. Pierrot-Deseilligny and the audience of the MicMac forum (forum-micmac.forumprod.com) are acknowledged for fruitful discussions and technical support.

\section{References}

Barr, Iestyn D., and Harold Lovell. 2014. "A review of topographic controls on moraine distribution." Geomorphology 226: 44-64. http://dx.doi.org/10.1016/j.geomorph. 2014.07 .030$.

Bennett, Matthew R. 2001. "The morphology, structural evolution and significance of push moraines." Earth Science Reviews 53 (3-4): 197-236.

Bennett, Matthew R., Michael J. Hambrey, David Huddart, Neil F. Glasser, and Kevin Crawford. 1999. "The landform and sediment assemblage produced by a tidewater glacier surge in Kongsfjorden, Svalbard." Quaternary Science Reviews 18 (1011): 1213-1246. http://www.sciencedirect.com/science/article/pii/S0277379198900415.

Bernard, É., J.M. Friedt, F. Tolle, M. Griselin, G. Martin, D. Laffly, and C. Marlin. 2013. "Monitoring seasonal snow dynamics using ground based high resolution photography (Austre Lovénbreen, Svalbard, 79N)." ISPRS Journal of Photogrammetry and Remote Sensing 75: 92-100. http://www.sciencedirect.com/science/article/pii/ S092427161200189X.

Birks, Hilary H., Ingelinn Aarnes, Anne E. Bjune, Stephen J. Brooks, Jostein Bakke, Norbert Kühl, and H. John B Birks. 2014. "Lateglacial and early-Holocene climate variability reconstructed from multi-proxy records on Andøya, northern Norway." Quaternary Science Reviews 89: 108-122. http://dx.doi.org/10.1016/j.quascirev.2014.01. 018.

Colomina, I., and P. Molina. 2014. "Unmanned aerial systems for photogrammetry and remote sensing: A review." ISPRS Journal of Photogrammetry and Remote Sensing 92: 79-97. http://linkinghub.elsevier.com/retrieve/pii/S0924271614000501.

Evans, David J A. 2009. "Controlled moraines: origins, characteristics and palaeoglaciological implications." Quaternary Science Reviews 28 (3-4): 183-208. http://dx.doi. org/10.1016/j.quascirev.2008.10.024.

Ewertowski, Marek W., and Aleksandra M. Tomczyk. 2015. "Quantification of the ice-cored moraines' short-term dynamics in the high-Arctic glaciers Ebbabreen and Ragnarbreen, 
Petuniabukta, Svalbard." Geomorphology 234: 211-227. http://dx.doi.org/10.1016/ j.geomorph.2015.01.023.

Ferguson, R.I. 1999. "Snowmelt runoff models." Progress in Physical Geography 23 (2): 205-227. http://openurl.ingenta.com/content/xref?genre=article\&issn= 0309 $-1333 \&$ volume $=23 \&$ i ssue $=2 \&$ spage $=205$.

Friedt, J-M., F. Tolle, É. Bernard, M. Griselin, D. Laffly, and C. Marlin. 2011. "Assessing the relevance of digital elevation models to evaluate glacier mass balance: application to Austre Lovénbreen (Spitsbergen, $79^{\circ}$ N)." Polar Record 48 (01): 2-10. http://journals. cambridge.org/abstract_S0032247411000465.

Griselin, M., and C. Marlin. 1998. "Origin of the Water Circulation in the moraine plain of the Loven East Glacier (Spitsbergen)." In Proc. of the 4th International Symposium Glacier Caves and Cryokarst in Polar Regions, 61-71. 1-6 sept..

Hagen, JO, and Olav Liestøl. 1990. "Long-term glacier mass-balance investigations in Svalbard, 195088." Annals of Glaciology http://www.igsoc.org/annals.old/14/igs_ annals_vol14_year1990_pg102-106.pdf.

Hock, Regine. 2005. "Glacier melt: a review of processes and their modelling." Progress in Physical Geography 29 (3): 362-391. http://ppg.sagepub.com/cgi/doi/10.1191/ 0309133305pp453ra.

Hodgkins, Richard. 1997. "Glacier hydrology in Svalbard, Norwegian high arctic." Quaternary Science Reviews 16 (9): 957-973. http://www.sciencedirect.com/science/ article/pii/S0277379197000322.

Humlum, Ole. 2000. "The geomorphic significance of rock glaciers: estimates of rock glacier debris volumes and headwall recession rates in West Greenland." Geomorphology 35 (12): 41-67. http://www.sciencedirect.com/science/article/pii/ S0169555X00000222.

Irvine-Fynn, T. D L, N. E. Barrand, P. R. Porter, A. J. Hodson, and T. Murray. 2011. "Recent High-Arctic glacial sediment redistribution: A process perspective using airborne lidar." Geomorphology 125 (1): 27-39. http://dx.doi.org/10.1016/j.geomorph . 2010.08 .012$.

Kenner, R., Y. Bühler, R. Delaloye, C. Ginzler, and M. Phillips. 2014. "Monitoring of high alpine mass movements combining laser scanning with digital airborne photogrammetry." Geomorphology 206: 492-504. http://dx.doi.org/10.1016/j.geomorph. 2013. 10.020 .

Kohler, J., T. D. James, T. Murray, C. Nuth, O. Brandt, N. E. Barrand, H. F. Aas, and a. Luckman. 2007. "Acceleration in thinning rate on western Svalbard glaciers." Geophysical Research Letters 34 (18): L18502. http://doi.wiley.com/10.1029/ 2007 GL030681.

Lefauconnier, Bernard, Jon Ove Hagen, Jon Borre, Kjetil Melvold, and Elisabeth Isaksson. 1993. "Glacier balance trends in the Kongsfjorden area, western Spitsbergen, Svalbard , in relation to the climate." Polar Research 18 (2): 307-313.

Lønne, Ida. 2007. "Reply to Lucas, S., Nicholson, L.I. Humlums O. (2006). Comment on Lønne and Lyså (2005): Deglaciation dynamics following the Little Ice Age on Svalbard: Implications for shaping of lanscapes at high latitudes. Geomorphology 72, 300-319." Geomorphology 86 (1-2): 217-218.

Lucieer, Arko, Darren Turner, Diana H. King, and Sharon a. Robinson. 2014. "Using an Unmanned Aerial Vehicle (UAV) to capture micro-topography of Antarctic moss beds." International Journal of Applied Earth Observation and Geoinformation 27: 5362. http://linkinghub.elsevier.com/retrieve/pii/S0303243413000603.

Midgley, Nicholas G., Simon J. Cook, David J. Graham, and Toby N. Tonkin. 2013. "Origin, evolution and dynamic context of a Neoglacial lateral-frontal moraine at Austre Lovénbreen, Svalbard." Geomorphology 198: 96-106. http://dx.doi.org/10.1016/j. geomorph.2013.05.017.

Moholdt, Geir, Christopher Nuth, Jon Ove Hagen, and Jack Kohler. 2010. "Recent elevation changes of Svalbard glaciers derived from ICESat laser altimetry." Remote Sensing of Environment 114 (11): 2756-2767. http://www. sciencedirect.com/science/ article/pii/S0034425710001987. 
Niethammer, U., M.R. James, S. Rothmund, J. Travelletti, and M. Joswig. 2012. "UAV-based remote sensing of the Super-Sauze landslide: Evaluation and results." Engineering Geology 128: 2-11. http://linkinghub.elsevier.com/retrieve/pii/ S0013795211000755.

Nowak, Aga, and Andy Hodson. 2013. "Hydrological response of a High-Arctic catchment to changing climate over the past 35 years : a case study of Bayelva watershed, Svalbard." Polar Research 1 (1): 1-16.

Oerlemans, J. 2005. "Extracting a climate signal from 169 glacier records.." Science (New York, N.Y.) 308 (5722): 675-7. http://www.ncbi.nlm.nih.gov/pubmed/15746388.

Park, Hotaek, John E. Walsh, Yongwon Kim, Taro Nakai, and Tetsuo Ohata. 2013. "The role of declining Arctic sea ice in recent decreasing terrestrial Arctic snow depths." Polar Science 7 (2): 174-187. http://linkinghub.elsevier.com/retrieve/pii/ S1873965212000448.

Paul, F. 2010. "The influence of changes in glacier extent and surface elevation on modeled mass balance." The Cryosphere 4 (4): 569-581. http://www.the-cryosphere.net/4/ $569 / 2010 /$.

Rachlewicz, Grzegorz. 2010. "Paraglacial Modifications of Glacial Sediments Over Millennial to Decadal Time-Scales in the High Arctic (Billefjorden, Central Spitsbergen, Svalbard)." Quaestiones Geographicae 29 (3): 59-67.

Radić, Valentina, Andrew Bliss, a. Cody Beedlow, Regine Hock, Evan Miles, and J. Graham Cogley. 2013. "Regional and global projections of twenty-first century glacier mass changes in response to climate scenarios from global climate models." Climate Dynamics 42 (1-2): 37-58. http://link. springer.com/10.1007/s00382-013-1719-7.

Rippin, David M., Andrew Pomfret, and Nigel King. 2015. "High resolution mapping of supra-glacial drainage pathways reveals link between micro-channel drainage density, surface roughness and surface reflectance." Earth Surface Processes and Landforms 40 (10): 1279-1290.

Rutter, Nick, Andy Hodson, Tristram Irvine-Fynn, and Monica Kristensen Solås. 2011. "Hydrology and hydrochemistry of a deglaciating high-Arctic catchment, Svalbard." Journal of Hydrology 410 (12): 39-50. http://www.sciencedirect.com/science/ article/pii/S0022169411006226.

Westoby, M.J., J. Brasington, N.F. Glasser, M.J. Hambrey, and J.M. Reynolds. 2012. "Structure-from-Motion' photogrammetry: A low-cost, effective tool for geoscience applications." Geomorphology 179: 300-314. http://linkinghub.elsevier.com/ retrieve/pii/S0169555X12004217.

Wiesmann, Samuel, Ladina Steiner, Milo Pozzi, and Claudio Bozzini. 2012. "Reconstructing Historic Glacier States Based on Terrestrial Oblique Photographs." AutoCarto 2012 1-14. http://www.cartogis.org/docs/proceedings/2012/Wiesmann etal_AutoCarto2012.pdf.

Wright, Andrew Philip. 2005. "The Impact of Meltwater Refreezing on the Mass Balance of a High Arctic Glacier." Ph.D. thesis. Bristol. 